\section{SAT0244 IMPACT OF 12 WEEKS OF UPADACITINIB TREATMENT ON INDIVIDUAL AND COMPOSITE DISEASE MEASURES IN PATIENTS WITH RHEUMATOID ARTHRITIS AND INADEQUATE RESPONSE TO CONVENTIONAL SYNTHETIC OR BIOLOGIC DMARDS}

R. van Vollenhoven ${ }^{1}$, R. Dore ${ }^{2}$, K. Chen ${ }^{3}$, H. S. Camp ${ }^{3}$, J. Enejosa ${ }^{3}$, T. Shaw ${ }^{3}$, J. L. Suboticki ${ }^{3}$, S. Hall ${ }^{4} .{ }^{1}$ Amsterdam Rheumatology and Immunology Center ARC, Amsterdam, Netherlands, ${ }^{2}$ Univ of California, Los Angeles, Los Angeles, ${ }^{3} \mathrm{AbbVie}$ N Chicago, United States, ${ }^{4}$ Dept of Medicine, Monash Univ, Cabrini Health and Emeritus Research, Malvern, Australia

Background: Upadacitinib (UPA), an oral, JAK1-selective inhibitor, demonstrated efficacy through 12 and 24 weeks (wks) in phase 3 trials of patients (pts) with active rheumatoid arthritis (RA) and inadequate response (IR) to csDMARDs and bDMARDs, respectively. ${ }^{1,2}$ Efficacy evaluations at Wk 12 are an important assessment point according to T2T recommendations. ${ }^{3}$

Objectives: To assess the impact of UPA at 12 wks on individual and composite measures of RA disease activity.

Methods: Pts received UPA $15 \mathrm{mg}$ or $30 \mathrm{mg}$ once daily (QD) or PBO for 12 wks in two phase 3 trials. SELECT NEXT ${ }^{1}$ and SELECT BEYOND ${ }^{2}$ enrolled csDMARD- and bDMARD-IR pts, respectively. For this investigation, responses at Wk 12 , were defined as $\geq 50 \%$ improvement in ACR components. Among ACR50 responders, the proportions of pts achieving $\geq 50 \%$ improvement in all 7 components of the ACR response criteria [Tender Joint Count (TJC68), Swollen Joint Count (SJC66), Pt Global Assessment (PtGA), Physician Global Assessment (PhGA), Pt Pain, Health Assessment Questionnaire-Disability Index (HAQ$\mathrm{DI}$ ), and high sensitive $\mathrm{C}$-reactive protein (hsCRP)] were assessed. Differences in the cumulative distributions of CDAI, DAS28-CRP, and SDAI between baseline $(B L)$ and Wk 12 were assessed. All analyses were based on observed data without imputation.

Results: Pts in both studies, on average, had established, moderate to severe $\mathrm{RA}$ at BL, with (mean) disease durations of 7.3 and 13.2 years, CDAl of 38.2 and 40.9 , in csDMARD-IR and bDMARD-IR pts, respectively; $53 \%$ of bDMARD-IR pts had exposure to $\geq 2$ bDMARDs. ${ }^{1,2}$ In both populations, significantly more pts on UPA vs $\mathrm{PBO}$ achieved $\geq 50 \%$ improvement in each ACR component at Wk 12 (Table). Among pts who achieved ACR50 at Wk 12, approximately one-half of the csDMARD-IR and one-third of the bDMARD-IR pts achieved $\geq 50 \%$ improvement in all 7 ACR components. While there were no differences at $B L$, cumulative distributions of CDAI, DAS28-CRP, and SDAl separated by treatment at Wk 12 $(p<0.001)$; for the lowest quartiles for UPA $15 \mathrm{mg}$ and $30 \mathrm{mg}$ vs PBO, CDAl levels dropped to 6.2 and 5.1 vs 12.5 in csDMARD-IR; and 7.2 and 8.2 vs 13.1 in bDMARD-IR

\begin{tabular}{|c|c|c|c|c|c|c|c|}
\hline \multicolumn{8}{|c|}{ Proportions of Patients Achieving $50 \%$ Improvements in Core Components of the ACR Score at Week 12} \\
\hline & & \multicolumn{3}{|c|}{$\begin{array}{l}\text { SELECT-NEXT } \\
\text { (CSDMARD-IR) }\end{array}$} & \multicolumn{3}{|c|}{$\begin{array}{l}\text { SELECT-BEYOND } \\
\text { (bDMARD-IR) }\end{array}$} \\
\hline & & $\mathrm{N}$ & $\frac{\text { (CSDMARD- }}{\mathrm{n}(\%)}$ & $\Delta$ from & $\mathrm{N}$ & $\frac{(\text { (bDMARD-1 }}{n(\%)}$ & $\Delta$ from \\
\hline \multirow{3}{*}{$\begin{array}{l}\mathrm{TJC} \geq 50 \% \\
\text { Improvement }\end{array}$} & PBO & 207 & $95(45.9)$ & $\cdot$ & 147 & $68(46.3)$ & \\
\hline & UPA 15 & 210 & $140(66.7)^{* * *}$ & $20.8^{* * *}$ & 157 & $116(73.9)^{* * *}$ & $27.6^{* * *}$ \\
\hline & UPA30 & 201 & $143(71.1)^{* * *}$ & $25.2^{* * *}$ & 149 & $105(70.5)^{* * *}$ & $24.2^{* * *}$ \\
\hline \multirow{3}{*}{$\begin{array}{l}\text { SJC } 250 \% \\
\text { Improvement }\end{array}$} & PBO & 207 & $114(55.1)$ & $\cdot$ & 147 & $81(55.1)$ & $\cdot$ \\
\hline & UPA 15 & 210 & $153(72.9)^{* * * *}$ & $17.8^{* * *}$ & 157 & $123(78.3)^{* * * *}$ & $23.2^{* * *}$ \\
\hline & UPA30 & 201 & $158(78.6)^{* * *}$ & $23.5^{* * *}$ & 149 & $109(73.2)^{* * *}$ & $18.1^{* * *}$ \\
\hline \multirow{3}{*}{$\begin{array}{l}\text { Pain } \geq 50 \% \\
\text { Improvement }\end{array}$} & PBO & 206 & $42\{20.4\}$ & & 145 & $34(23.4)$ & \\
\hline & UPA 15 & 207 & $112(54.1)^{* * *}$ & $33.7^{* * * *}$ & 156 & $67(42.9)^{* * *}$ & $19.5^{* * *}$ \\
\hline & UPA30 & 200 & $111(55.5)^{* * *}$ & $35.1^{* * *}$ & 146 & $70(47.9)^{* * *}$ & $24,5^{* * *}$ \\
\hline \multirow{3}{*}{$\begin{array}{l}\text { PtGA } 250 \% \\
\text { Improvement }\end{array}$} & PBO & 206 & $49(23.8)$ & 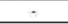 & 145 & $33(22.8)$ & - \\
\hline & UPA1 & 207 & $108(52.2)^{* * *}$ & $28.4^{* * *}$ & 156 & $73(46.8)^{* * *}$ & $24.0^{* * *}$ \\
\hline & UPA30 & 200 & $109(54.5)^{* * *}$ & $30.7^{* * *}$ & 147 & $74(50,3)^{* * *}$ & $27.5^{* * *}$ \\
\hline \multirow{3}{*}{$\begin{array}{l}\text { PhGA } 250 \% \\
\text { Improvement }\end{array}$} & PBO & 192 & $74(38.5)$ & & 137 & $56(40.9)$ & \\
\hline & UPA 15 & 193 & $129(66.8)^{* * * *}$ & $28.3^{* * *}$ & 150 & $97(64.7)^{* * *}$ & $238^{* * *}$ \\
\hline & UPA30 & 187 & $140(74.9)^{* * *}$ & $36.4^{* * *}$ & 137 & $94(68.6)^{* * *}$ & $27,7^{* * *}$ \\
\hline \multirow{3}{*}{$\begin{array}{l}\text { HAQ-DI } \geq 50 \% \\
\text { Improvement }\end{array}$} & PBO & 206 & $48(23.3)$ & 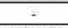 & 145 & $22(15.2)$ & $\cdot$ \\
\hline & UPA15 & 206 & $91(44.2)^{* * *}$ & $20.9^{* * *}$ & 156 & $41(26.3)^{*}$ & $11.1^{*}$ \\
\hline & UPA30 & 200 & $83(41.5)^{j * *}$ & $18.2^{* * * *}$ & 146 & $41(28.1)^{* * *}$ & $12.9^{* *}$ \\
\hline \multirow{3}{*}{$\begin{array}{l}\text { hsCRP } \geq 50 \% \\
\text { Improvement }\end{array}$} & PBO & 207 & $38(18.4)$ & & 146 & $39(26.7)$ & \\
\hline & UPA 15 & 209 & $159(76.1)^{* * *}$ & $57.7^{* * *}$ & 155 & $114(73.5)^{* * *}$ & $46.8^{* * *}$ \\
\hline & UPA30 & 201 & $145(72.1)^{* * * *}$ & $53.7^{* * * *}$ & 146 & $100(68.5)^{* * *}$ & $418^{* * *}$ \\
\hline \multirow{3}{*}{$\begin{array}{l}\geq 50 \% \\
\text { Improvement } \\
\text { in all } 7 \text { ACR }\end{array}$} & PBO & 32 & $2(6.3)$ & - & 20 & $2(10)$ & 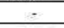 \\
\hline & UPA1 & 84 & $38(45.2)^{* * *}$ & $38.9^{* * *}$ & 56 & $19(33.9)$ & 23.9 \\
\hline & UPA30 & 94 & $39(41.5)^{* * *}$ & $35.2^{* * *}$ & 58 & $19(32.8)$ & 22.8 \\
\hline
\end{tabular}

Conclusions: In pts with an insufficient response to either csDMARDs or bDMARDs, treatment responses at $12 \mathrm{wks}$ were observed in significantly higher proportions with UPA vs PBO. Favorable effects with UPA were seen in the composite scores and the individual parameters, including PROs and acute-phase reactants.

\section{REFERENCES:}

[1] Burmester, et al., Arthritis Rheumatol 2017;69:S10

[2] Genovese, et al. Arthritis Rheumatol 2017;69:S10.

[3] Smolen, et al. 2015. doi:10.1136/annrheumdis-2015-207524
Acknowledgements: AbbVie Inc was the study sponsor, contributed to study design, data collection, analysis \& interpretation, and to writing, reviewing, and approval of final version. Medical writing support was provided by Naina Barretto $\mathrm{PhD}$, of AbbVie, Inc.

Disclosure of Interest: R. van Vollenhoven Grant/research support from: AbbVie, Amgen, Bristol-Myers Squibb, GlaxoSmithKline, Pfizer, Roche, and UCB, Consultant for: AbbVie, AstraZeneca, Biotest, Bristol-Myers Squibb, Celgene, Crescendo, GlaxoSmithKline, Janssen, Lilly, Merck, Novartis, Pfizer, Roche, UCB, and Vertex, Speakers bureau: AbbVie, AstraZeneca, Biotest, Bristol-Myers Squibb, Celgene, Crescendo, GlaxoSmithKline, Janssen, Lilly, Merck, Novartis Pfizer, Roche, UCB, and Vertex, R. Dore: None declared, K. Chen Shareholder of: AbbVie, Employee of: AbbVie, H. Camp Shareholder of: AbbVie, Employee of: AbbVie, J. Enejosa Shareholder of: AbbVie, Employee of: AbbVie, T. Shaw Shareholder of: AbbVie, Employee of: AbbVie, J. Suboticki Shareholder of: AbbVie, Employee of: AbbVie, S. Hall: None declared DOI: 10.1136/annrheumdis-2018-eular.5897

\section{SAT0245 AZD9567: A NOVEL ORAL SELECTIVE GLUCOCORTICOID RECEPTOR MODULATOR, DEMONSTRATED TO HAVE AN IMPROVED THERAPEUTIC RATIO COMPARED TO PREDNISOLONE IN PRE-CLINICAL STUDIES, IS SAFE AND WELL TOLERATED IN FIRST CLINICAL STUDY.}

R. Hendrickx ${ }^{1}$, T. Hegelund-Myrbäck ${ }^{2}$, M. Dearman ${ }^{1}$, S. Prothon ${ }^{2}$, G. Edenro ${ }^{1}$, J. Leander ${ }^{2}$, R. Fuhr ${ }^{3}$, T. Körnicke ${ }^{3}$, P. Svanberg ${ }^{1}$, A. R. Berggren ${ }^{4}$, T. Drmota ${ }^{1}$ C. Keen ${ }^{1}$, U. G. Eriksson ${ }^{2} .{ }^{1}$ Respiratory Inflammation \& Autoimmunity, ${ }^{2}$ Early Clinical Development, IMED Biotech Unit, AstraZeneca, Gothenburg, Sweden, ${ }^{3}$ Early Phase Clinical Unit, Parexel, Berlin, Germany, ${ }^{4}$ Global Medicines Development, AstraZeneca, Gothenburg, Sweden

Background: Glucocorticoids $(\mathrm{GC})$ are highly effective in the treatment of inflammatory diseases but chronic treatment is limited by severe adverse effects including hyperglycemia and bone re-modelling. AZD9567 is a novel, orally delivered, non-steroidal Selective Glucocorticoid Receptor Modulator (SGRM) with the potential to demonstrate an improved therapeutic ratio (TR) compared to steroidal GC such as prednisolone.

Objectives: To investigate the effects of AZD9567 and prednisolone on biomarkers of inflammation, glucose metabolism and bone re-modelling in pre-clinical models. To confirm the inhibition of inflammatory biomarker production and to evaluate safety and pharmacokinetics (PK) of AZD9567 in a first clinical study. Methods: The effects on biomarkers of gluconeogenesis (tyrosine aminotransferase, TAT mRNA), bone re-modelling (osteoprotegerin, OPG mRNA) and antiinflammatory activity (TNF $\alpha$ ) were evaluated in vitro using human hepatocytes, an osteoblast cell line and whole blood, respectively. In vivo, effects on plasma insulin and osteocalcin levels were compared with inhibition of whole blood TNFo release in rats. Efficacy was evaluated in an adjuvant-induced rat arthritis model. In a human single ascending dose study the effect of AZD9567 on TNF $\alpha$ inhibition was investigated, together with assessment of safety profile and PK.

Results: Potent in vitro anti-inflammatory activity $\left(\mathrm{IC}_{50} 6.2 \mathrm{nM}, 7\right.$-fold more potent than prednisolone) was observed, whilst no effect on TAT mRNA expression in human hepatocytes was detected for AZD9567 (prednisolone $\mathrm{EC}_{50} 92$ $n M$ ). This resulted in a substantially better TR compared to prednisolone. Furthermore, AZD9567 showed a 7-fold superior TR compared to prednisolone based on OPG mRNA expression in human osteoblasts. An improved profile for AZD9567 was also demonstrated in vivo in the rat (TR of 7.5 for osteocalcin and 3.6 for insulin). Efficacy was demonstrated in the rat arthritis model where an inhibition of joint inflammation was observed $\left(E_{50} 0.1 \mathrm{mg} / \mathrm{kg}\right)$. In human, AZD9567 was safe and well tolerated after single doses $(2-155 \mathrm{mg})$. The PK properties showed a fast absorption with a median $t_{\max }$ of 0.50 to 1.25 hour and a dose-dependent increase in exposure, with a mean terminal half-life of 3.9 to 6.4 hours, suitable for a once daily dosing regimen. TNFa release was inhibited in a concentration-dependent manner $\left(\mathrm{IC}_{50, \mathrm{u}} 5.2 \mathrm{nM}\right)$, consistent with pre-clinical findings.

Conclusions: In pre-clinical models, AZD9567 demonstrated anti-inflammatory activity with a reduced effect on gluconeogenesis and biomarkers of bone re-modelling compared to prednisolone. Single oral dosing of AZD9567 was well tolerated and showed good PK properties in healthy subjects. These results support that AZD9567 has the potential to improve the treatment of several inflammatory diseases with a better TR compared to prednisolone. AZD9567 is currently in clinical evaluation in rheumatoid arthritis.

Disclosure of Interest: R. Hendrickx Employee of: AstraZeneca, T. HegelundMyrbäck Employee of: AstraZeneca, M. Dearman Employee of: AstraZeneca, S. Prothon Employee of: AstraZeneca, G. Edenro Employee of: AstraZeneca (forme employee), J. Leander Employee of: AstraZeneca, R. Fuhr Employee of: Parexel International $\mathrm{GmbH}$, T. Körnicke Employee of: Parexel International GmbH, P. Svanberg Employee of: AstraZeneca, A. Berggren Employee of: AstraZeneca, T. Drmota Employee of: AstraZeneca (former employee), C. Keen Employee of AstraZeneca, U. Eriksson Employee of: AstraZeneca 